\title{
A GIS-BASED CULTURAL HERITAGE STUDY FRAMEWORK ON CONTINUOUS SCALES: A CASE STUDY ON 19TH CENTURY MILITARY INDUSTRIAL HERITAGE
}

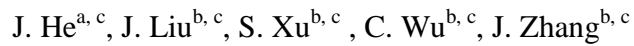 \\ a Institute of Digital Design, Tianjin University, Tianjin, China - janushe@tju.edu.cn \\ b International Research Center for Chinese Cultural Heritage Conservation, Tianjin University, Tianjin, China - \\ liujing1002@gmail.com,1421750993@qq.com,wu.cong@hotmail.com,825209141@qq.com
} c School of Architecture, Tianjin University, Tianjin, China

Commission XX

KEY WORDS: Cultural Heritage, GIS, BIM, Historical Context, Continuous Scales

\begin{abstract}
:
This paper presents a framework of introducing GIS technology to record and analyse cultural heritages in continuous spatial scales. The research team is developing a systematic approach to support heritage conservation research and practice on historical buildings, courtyards, historical towns, and archaeological sites ad landscapes. These studies are conducted not only from the property or site scales, but also investigated from their contexts in setting as well as regional scales. From these continues scales, authenticity and integrity of a heritage can be interpreted from a broader spatial and temporal context, in which GIS would contribute through database, spatial analysis, and visualization. The case study is the construction of a information indexing framework of Dagu Dock industrial heritage to integrate physical buildings, courtyards, natural settings as well as their intangible characteristics which are affiliated to the physical heritage properties and presented through historical, social and culture semantics. The paper illustrates methodology and content of recording physical and social/cultural semantics of culture heritages on different scales as well as connection between different levels of database.
\end{abstract}

\section{INTRODUCTION}

\subsection{Background}

Geographical information system (GIS) has been introduced in cultural heritage conservation from early 1990s, and been blooming in recent year in both practical projects and contextual historical and archaeological studies. Although many progress had been made in this field, but as discussed in the following literature review, most of these GIS systems have either difficulty for supporting contextual interpretation through limited physical recordings, or unable to deal with specific heritage problem because of the large scales of their database system. In order to investigate cultural heritages from a broader spatial as well as in-depth historical context, innovative approaches based on GIS technology are necessary.

This paper presents a framework of introducing GIS technology to record and analyse cultural heritages in continuous spatial scales. From the perspective of "historical GIS (H-GIS)", the research team is developing a systematic approach to support heritage conservation research and practice on historical buildings, courtyards, historical towns, and archaeological sites ad landscapes. These studies are conducted not only from the property or site scales, but also investigated from their contexts in setting as well as regional scales. From these continues scales, authenticity and integrity of a heritage can be interpreted from broader spatial and temporal contexts, in which GIS would contribute through database, spatial analysis, and visualization. Through a case study on industrial heritage, the paper illustrates the methodology and content of recording physical and social/cultural semantics of culture heritages on different scales as well as connection between different levels of database. The proposed approach is helpful to reveals new historical spatial phenomena which traditional methods are difficult to find, and enhances our understanding of heritage's authenticity to support heritage conservation planning, design and management.

\subsection{Industrial Heritages}

Industrial heritages consist of the remains of industrial culture which are of historical, technological, social, architectural or scientific values. It includes buildings, machinery, workshops, mills, factories, mines and sites for processing and refining, warehouses, stores, facilities where energy is generated, transmitted and used, transport and all its infrastructure, as well as places used for social activities related to industry such as residence, worship and education (TICCIH, 2003). In recent years, industrial heritage conservation has attracted more and more attention in China. By 2014, there are more than 300 industrial heritages have been inscribed as National Key Cultural Relics Protection Units. In this circumstance, information collection and management of this kind of heritages has become an important issue for Chinese heritage conservation and related research. However, lack of basic information, incomplete documentation and insufficient of awareness of information management and utilization have restricted systematic and scientific protection of industrial heritages.

\subsection{The Case Study}

The research team select the Tianjin Dagu Dock which belonged to Beiyang Navy of Qing Dynasty of China as a case study. According to general industrial heritage conservation requirements and the specific characteristics of the case study, the research team constructs information indexing framework of Dagu Dock industrial heritage through a combination of GIS 
and building information modelling (BIM), to integrate physical buildings, courtyards, natural settings, urban contexts as well as their intangible characteristics which are affiliated to the physical heritage properties and presented through historical, social and culture semantics. The paper illustrates the methodology and content of recording physical and social/cultural semantics of culture heritages on different scales as well as connection between different levels of database.

\section{LITERATURE REVIEW}

\subsection{GIS as Heritage Conservation Support}

As a "spatial toolbox" (Wheatley and Gillings 2002) for archaeological, historical, cultural and social investigation, GIS has become an important technology for cultural heritage conservation in the past two decades. In the discipline of heritage conservation, GIS technology was firstly adopted in UNESCO World Heritage Site (WHS) management in 1992 to establish the Angkor Zoning and Environment Management Plan (ZEMP) (Wager 1995; Fletcher, et al., 2007). Based on UNESCO's technical experience, a GIS-based heritage management manual published in 1999 demonstrated the knowledge on and broad level of interest in GIS technological and methodological developments among the most cutting-edge groups working on heritage conservation (Box, 1999).

This manual was translated into Chinese and published in 2001. Introduction of GIS in heritage conservation in China also started at the same period. An earlier typical application is the historical town conservation of Xijindu, Zhejiang Province done by Southeast University in 2000 (Hu, et al., 2002). In 2006, Ministry of Science and Technology of China put tremendous resources on a key project named "Spatial Information Technology Application in Great Site Conservation". This project investigated potential of spatial information technologies, which including GIS, remote sensing (RS), global position system (GPS), and virtual reality (VR), in cultural heritage conservation, and identified adapted methodology and suitable technologies in the context of practices in China. Grand Canal, a WHS was chosen as the demonstration case study to show the technical supports on conservation and development (Zhou et al., 2011). Research groups of Tsinghua University has also explored GIS application in different kind of projects in the same period. GIS documentation and visualization was applied to show the current situation of the building group of Houtu Temple of Jiexiu, Shanxi Province in its conservation planning (Zhang, 2008). A more detailed database was built on ArcGIS platform to record and analyze the multi-resource data of the East Hall of Fougang Temple of Wutai Mountain of Shanxi Province, including 3D laser scanning, detailed manual measuring and surveying, materials, broken and lost, and so on. This database called Culture Heritage Information System (CHIS) was designed for monitoring the healthy of the specific heritage property (Zhang et al., 2010). The earliest GIS application in industrial heritage in China is the database of Hangzhou Industrial Heritage Database. However, because of insufficient understanding on industrial heritage characteristics, there were shortcomings in data collection and database architecture in this case.

As shown in the ZEMP case, preference for GIS may due to the fact that the main task of the digital heritage conservation database at present is focus on documentation and delimitation, in which GIS is mostly effective (He, 2008). Furthermore, this application requirement and practical focuses on recording and management also caused that the GIS database take most of the efforts on heritages' physical phenomena. This kind of heritage GIS system always integrates comprehensive and very detailed documentation data on physical characteristics of heritage properties and settings through text descriptions, drawings, photographs (for example, Riveiro, et al., 2011), and 3D scanned or virtual models (Tsirliganis, et al., 2004; Styliadis, et al., 2009; Remondino, 2011; Rojas-Sola, et al., 2011). Most of these systems have a common problem that only use GIS for recording properties' position without further data integration through geo-referencing approach. Therefore, although within a same geospatial context, the abundant heritage information of individual property is always isolated and not able to be analysed through spatial approaches.

\subsection{BIM for Cultural Heritage}

BIM modeling which records construction details in 3D and semantics becomes a new topic in heritage conservation support recently (Pauwels, et al., 2008; San José-Alonso, et al., 2009; Oreni, et al., 2012), especially because of the current development of 3D surveying, modeling and visualization capability. The authors' research team is one of the pioneers of introducing BIM into this field by a heritage conservation project of Angkor (Wu, et al., 2011). Wu and his colleagues are continuously working on a cultural heritage information system for architectural property and the whole site management and conservation base on GIS and BIM integration in various Chinese heritages and WHSs, including Ta Keo Temple of Angkor, Dehe Garden of Summer Palace and Beihai in Beijing (Wu, 2012). More pure BIM test has been applied on industrial heritage by the same team ( $\mathrm{Du}, 2013)$. Recent academic exploration concentrates on collection and modelling of historical information which include semantics base on the study of Yellow Sea Research Society of Chemical Industry (Shi, et al., 2014). Relevant systems are from a perspective of professional requirement of information access and query on both large-scale site and small-scale building levels. They can be considered as the prior generations of what discussed in this research paper.

San José-Alonso and colleagues (2009) noticed that BIM integrated with 3D GIS had great potential for cultural heritage modeling and integrating intangible information records. In their system, 3D metadata of both was considered as the key in the system and data accessing and inquiry are principal functions. Since semantic elements are crucial in cultural heritage management, and 3D and hierarchy are almost equality significant for industrial heritages, City Geography Markup Language (CityGML) metadata is a good option. CityGML has been broadly introduced in most of the 3D cultural heritage and historical development studies in urban or large-scaled contexts (Alamouri and Kolbe, 2009; San José-Alonso et al., 2009; Limp, et al., 2010; Manferdini and Remondino, 2010).

\subsection{Shortcomings and Perspectives}

In general, although GIS system for cultural heritage do have the shortcomings on semantics and analytical application described in session 2.1, it is more mature than BIM applications from the database perspective as well as in academic research. However, required by conservation engineering and management, detailed documentation and visualization of building properties and their structure 
components or construction objects are not able to conducted solely through GIS system because of their complexity. Neither could any longitude monitoring on structure deformation be done in pure GIS. In that case, BIM technology can be a valuable supplement for the constrain of GIS database once reaching the scale of construction objects $(\mathrm{Wu}, 2012$; Liu, 2013). Information management system in continuous scales which can record, illustrate and analyse a comprehensive cultural heritage site, which include spatial scales on setting, building group, single properties, construction components, and their temporal changes, are essential in conservation practises. Integration of GIS and BIM technologies is the key approach to reach this goal.

\section{METHODOLOGY}

\subsection{The Continuous Scales}

The research team proposed a continuous scale composed by regional, site, and building scales as a framework to organize information, technologies and methodologies in GIS-based cultural heritage conservation studies.

1. Regional scale. In the regional scale, historical geographical paradigm leads spatial analytical model making. The historical performance of the heritage site on politics, economy, cultural and social development are revealed though GIS spatial analysis, especially historical phenomena related to large-scale movement, such as cultural routes.

2. Site scale. In the site scale, we study ecological and environmental constraints and impacts, logics of site selection, subjective or phenomenological meaning of the landscapes can also be interpreted through GIS-based spatial analysis. Historical contexts of sites, towns, or landscapes reconstructed in GIS-based model are key concerns of the historical interpretation meteorology of the proposed framework.

3. Building scale. From a contextual perspective, heritage properties or asserts can be understood though inherited historical spatial phenomenon on its landscape and site scales. Finer-scale analysis on how a single building cooperate with its setting can be illustrated though GIS investigation by following the finding revealed from the upper-level scale. Another important approach in this scale is interface between GIS and BIM. This integration is able to create a continuous-scale database on different LODs.

\subsection{The System for Industrial Heritage}

Information collection and recording of industrial heritage is experience, cognition and understanding, exploration, and evaluation of a heritage in various aspects of history, science, technology, humanities and arts. It contains not only the cognition of the entity and the space, but also the understanding of the spiritual meaning of the heritage, with value judgment and information selection. Information collection of industrial heritage is a series of life-cycle records and management, involving historical archives, documentation, conservation planning, construction, monitoring, maintenance, presentation use and so on. It will build a complete integrated heritage information service system (Di et al.,2012).

The proposed system uses spatial indices to record all heritage information in 3D format, including physical properties and semantic intangible attributes. For the physical parts, landscapes and constructions are organized in either CityGML or BIM data Semantic information of physical properties, like raster data, historical records, background documents and social/cultural descriptions are all draped as attributes of the 3D spatial elements.

Other than documentation, the database also serves as the analytical base of in-depth and multidisciplinary studies on the cultural heritage. In a broader scale, historical interpretation and spatial phenomena are investigated base on the spatial and semantic data, while studies on architecture and construction levels depends on the BIM data (Figure 1).

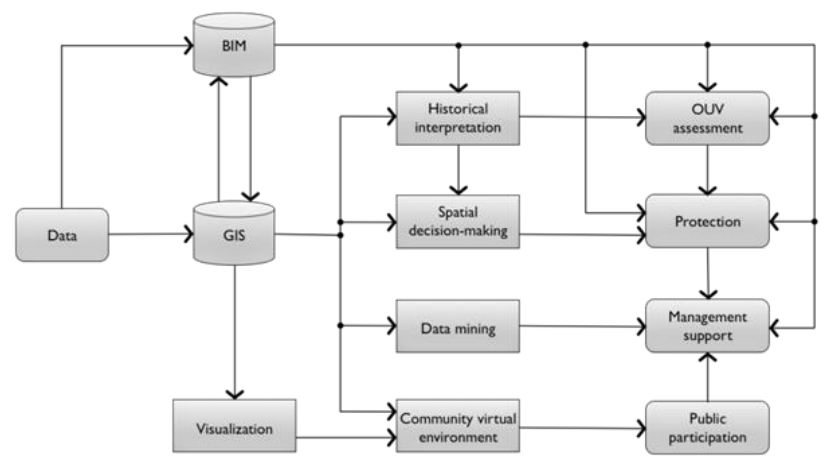

Figure 1. Structure of the proposed database $(\mathrm{He}, 2012)$

\subsection{The Case Study}

The research team chose Dagu Dock of Beiyang Navyas a case study. Dagu dock of Beiyang Navy is located in the lower reaches of the Haihe River in Binhai New Area of Tianjin (Figure 2). It was built in 1880 by Mr. Li Hongzhang, an exgovernor of Zhili Province of Qing Dynasty. Dagu dock of Beiyang Navy is the third modern shipyard established in China after following Fujian Ship-building Bureau and Jiangnan Manufacturing Bureau, and one of the most important military base in the late Qing Dynasty It was named the National Key Cultural Relics Protection Units in 2013, and planned to be nominated as a candidate for the World Heritage List together with other two earlier modern shipyards.

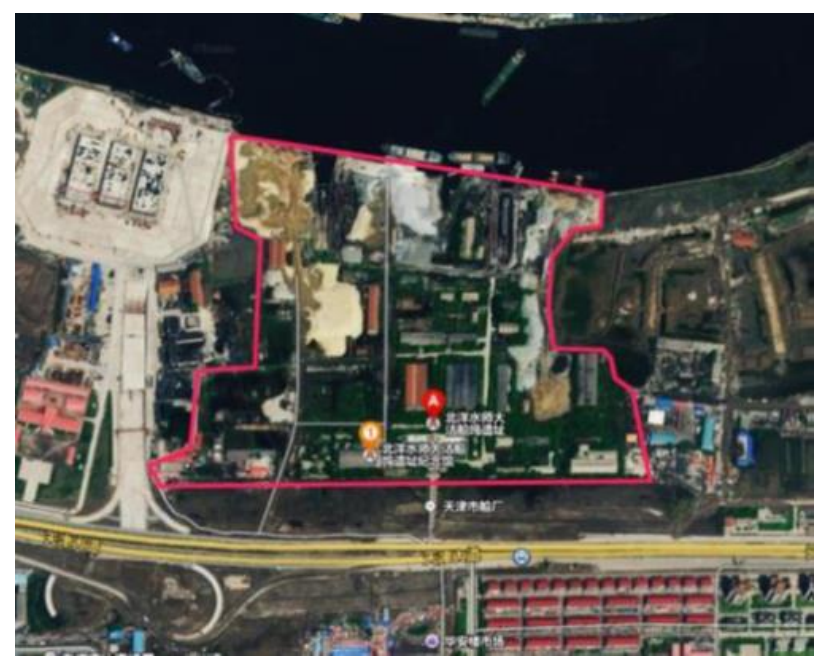

Figure 2. Location and proposed protection boundary (within the pink boundary) of the Dagu Dock of Beiyang Navy (International Research Center for Chinese Cultural Heritage Conservation of Tianjin University, 2014) 


\subsection{Data Acquisition}

In order to prepare the WHS application in the future, the local government and International Research Center for Chinese Cultural Heritage Conservation, e.g. the authors' research team, has launched a multi-year research program including site surveys, historic, social and architectural analyses, conservation planning, and heritage management. Since heritage site of the cultural heritage is large and composed by multiple kinds of properties, detailed site surveying and data acquisition have been planned during the next few years. Data planned to be collected includes historical records, maps, physical architectural recording, and social surveying shown in Table 1.

\begin{tabular}{|c|c|c|c|}
\hline Classification & Name & Source & Format \\
\hline Project file & $\begin{array}{c}\text { official document } \\
\text { or remarks, } \\
\text { Project Task } \\
\text { Standing Order } \\
\end{array}$ & $\begin{array}{l}\text { City government } \\
\text { bureaus }\end{array}$ & Digital \\
\hline $\begin{array}{l}\text { Historical } \\
\text { documents }\end{array}$ & $\begin{array}{c}\text { Local } \\
\text { Chronicles, } \\
\text { Inscriptions on a } \\
\text { tablet }\end{array}$ & $\begin{array}{l}\text { Governmental } \\
\text { archives }\end{array}$ & $\begin{array}{c}\text { None } \\
\text { (to be digitized } \\
\text { and rectified) }\end{array}$ \\
\hline $\begin{array}{l}\text { Historical } \\
\text { documents }\end{array}$ & $\begin{array}{l}\text { Historical } \\
\text { materials, } \\
\text { Contract }\end{array}$ & Archives & $\begin{array}{c}\text { Digital and } \\
\text { Traditional } \\
\text { paper } \\
\text { documents } \\
\text { (Photo ,Book) }\end{array}$ \\
\hline $\begin{array}{l}\text { Historical } \\
\text { documents }\end{array}$ & $\begin{array}{l}\text { Image, Old } \\
\text { photos }\end{array}$ & Internet, digitized & Digital \\
\hline $\begin{array}{l}\text { Historical } \\
\text { documents }\end{array}$ & $\begin{array}{l}\text { Historical } \\
\text { maintenance } \\
\text { record }\end{array}$ & Factory & $\begin{array}{c}\text { Digital and } \\
\text { Traditional } \\
\text { paper } \\
\text { documents }\end{array}$ \\
\hline $\begin{array}{l}\text { Historical } \\
\text { documents }\end{array}$ & $\begin{array}{c}\text { Related paper, } \\
\text { book and } \\
\text { Research Report }\end{array}$ & $\begin{array}{l}\text { Internet, Library, } \\
\text { Archives }\end{array}$ & $\begin{array}{c}\text { Digital and } \\
\text { Traditional } \\
\text { paper } \\
\text { documents } \\
\end{array}$ \\
\hline $\begin{array}{l}\text { Information and } \\
\text { drawing }\end{array}$ & $\begin{array}{c}\text { Aerial and } \\
\text { satellite photos }\end{array}$ & $\begin{array}{c}\text { City government } \\
\text { and Surveying } \\
\text { Bureau, overseas } \\
\text { archives, } \\
\text { commercial satellite } \\
\text { image distribution } \\
\text { services, etc. }\end{array}$ & geo-referenced \\
\hline $\begin{array}{l}\text { Information and } \\
\text { drawing }\end{array}$ & $\begin{array}{c}\text { Digital Line } \\
\text { Graphic(DLG) }\end{array}$ & $\begin{array}{l}\text { City government } \\
\text { bureaus } \\
\end{array}$ & $\begin{array}{l}\text { Digital(dwg,jp } \\
\text { g,tif,etc.) }\end{array}$ \\
\hline $\begin{array}{l}\text { Information and } \\
\text { drawing }\end{array}$ & $\begin{array}{c}\text { Photo ,slide, } \\
\text { video, rubbings, } \\
\text { etc. }\end{array}$ & Internet, digitized & $\begin{array}{l}\text { Digital(jpg,ppt, } \\
\text { rmvb, etc.) }\end{array}$ \\
\hline $\begin{array}{c}\text { Basic } \\
\text { information }\end{array}$ & $\begin{array}{l}\text { Related building } \\
\text { materials of the } \\
\text { factory }\end{array}$ & Factory & $\begin{array}{c}\text { Digital and } \\
\text { Traditional } \\
\text { paper } \\
\text { documents } \\
\end{array}$ \\
\hline $\begin{array}{c}\text { Basic } \\
\text { information }\end{array}$ & $\begin{array}{c}\text { Related } \\
\text { equipment } \\
\text { materials of the } \\
\text { factory }\end{array}$ & Factory & $\begin{array}{c}\text { Digital and } \\
\text { Traditional } \\
\text { paper } \\
\text { documents } \\
\end{array}$ \\
\hline $\begin{array}{c}\text { Basic } \\
\text { information }\end{array}$ & $\begin{array}{l}\text { Climate, } \\
\text { pollution, } \\
\text { erosion, etc. }\end{array}$ & $\begin{array}{l}\text { New installation on } \\
\text { site }\end{array}$ & $\begin{array}{l}\text { Digital and } \\
\text { geo-referenced }\end{array}$ \\
\hline $\begin{array}{c}\text { Basic } \\
\text { information }\end{array}$ & $\begin{array}{c}\text { Archives of } \\
\text { Cultural heritage } \\
\text { protection unit }\end{array}$ & $\begin{array}{l}\text { City government } \\
\text { bureaus }\end{array}$ & $\begin{array}{c}\text { Digital and } \\
\text { Traditional } \\
\text { paper } \\
\text { documents }\end{array}$ \\
\hline $\begin{array}{l}\text { Environment } \\
\text { around }\end{array}$ & Nearby residents & Field survey & $\begin{array}{c}\text { Digital and } \\
\text { Traditional } \\
\text { paper } \\
\text { documents } \\
\end{array}$ \\
\hline $\begin{array}{l}\text { Environment } \\
\text { around }\end{array}$ & Master plan & $\begin{array}{c}\text { City government } \\
\text { bureaus }\end{array}$ & Digital \\
\hline $\begin{array}{l}\text { Surveying and } \\
\text { Mapping } \\
\text { Archives } \\
\end{array}$ & $\begin{array}{l}\text { 3D laser point } \\
\text { cloud }\end{array}$ & $\begin{array}{c}\text { Data } \\
\text { acquisition(2013) }\end{array}$ & $\begin{array}{c}\text { Digital and } \\
\text { geo-referenced }\end{array}$ \\
\hline $\begin{array}{l}\text { Surveying and } \\
\text { Mapping } \\
\text { Archives } \\
\end{array}$ & $\begin{array}{c}\text { 3D laser } \\
\text { scanning record } \\
\text { table }\end{array}$ & $\begin{array}{c}\text { Data } \\
\text { acquisition(2013) }\end{array}$ & Digital \\
\hline Urban planning & $\begin{array}{l}\text { Master plan, } \\
\text { regulatory plan, } \\
\text { tourism plan.etc. }\end{array}$ & $\begin{array}{l}\text { City government } \\
\text { bureaus }\end{array}$ & $\begin{array}{l}\text { Digital(word.sl } \\
\text { ide,etc.) }\end{array}$ \\
\hline Urban planning & $\begin{array}{l}\text { Environmental } \\
\text { protection plan }\end{array}$ & $\begin{array}{l}\text { City government } \\
\text { bureaus }\end{array}$ & $\begin{array}{c}\text { Digital(word.sl } \\
\text { ide,etc.) }\end{array}$ \\
\hline Urban planning & $\begin{array}{c}\text { Tourism statistics } \\
\text { and related }\end{array}$ & $\begin{array}{c}\text { City government } \\
\text { bureaus }\end{array}$ & $\begin{array}{l}\text { Digital(word.sl } \\
\text { ide,etc.) }\end{array}$ \\
\hline
\end{tabular}

\begin{tabular}{lccc}
\hline materials & & \\
\hline Urban planning & $\begin{array}{c}\text { The protection } \\
\text { planning of the } \\
\text { north navy's taku } \\
\text { dockyard }\end{array}$ & $\begin{array}{c}\text { City government } \\
\text { bureaus }\end{array}$ & $\begin{array}{c}\text { Digital(word.sl } \\
\text { ide,etc.) }\end{array}$ \\
\hline
\end{tabular}

Table 1. Heritage data collected for documentation

\subsection{Database Architecture for Continuous Scales}

Industrial heritage integrates physical buildings, courtyards, natural settings as well as their attached intangible characteristics which are affiliated to the physical heritage properties and presents through historical, social and culture semantics. These often contain multiple scales, such as from 啊 machine to a building, a factory, or an industrial district even to an industrial town.

By reference to urban planning, industrial heritage conservation planning and architectural design drawings, etc., the research team divides the spatial scale of industrial heritage into seven detailed scales shown in Figure 3 in order to organize heritage information. Different technologies are introduced to correspond to different levels of scale base on the research or practical questions, as well as data characteristics. Except the regional scale data (Figure 4), the CityGML database combine the level from the urban level and use 3D objects in lower levels of detail (LOD) in GIS system as basic unit. Higher LOD models are imported from BIM data. Organization of physical heritage properties and LOD levels can be found in more detail in section 4.1.

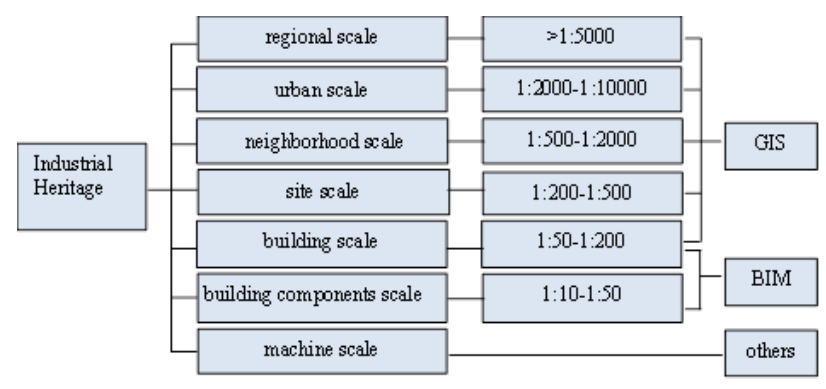

Figure 3. Spatial scale of an industrial heritage and corresponding technologies applied 


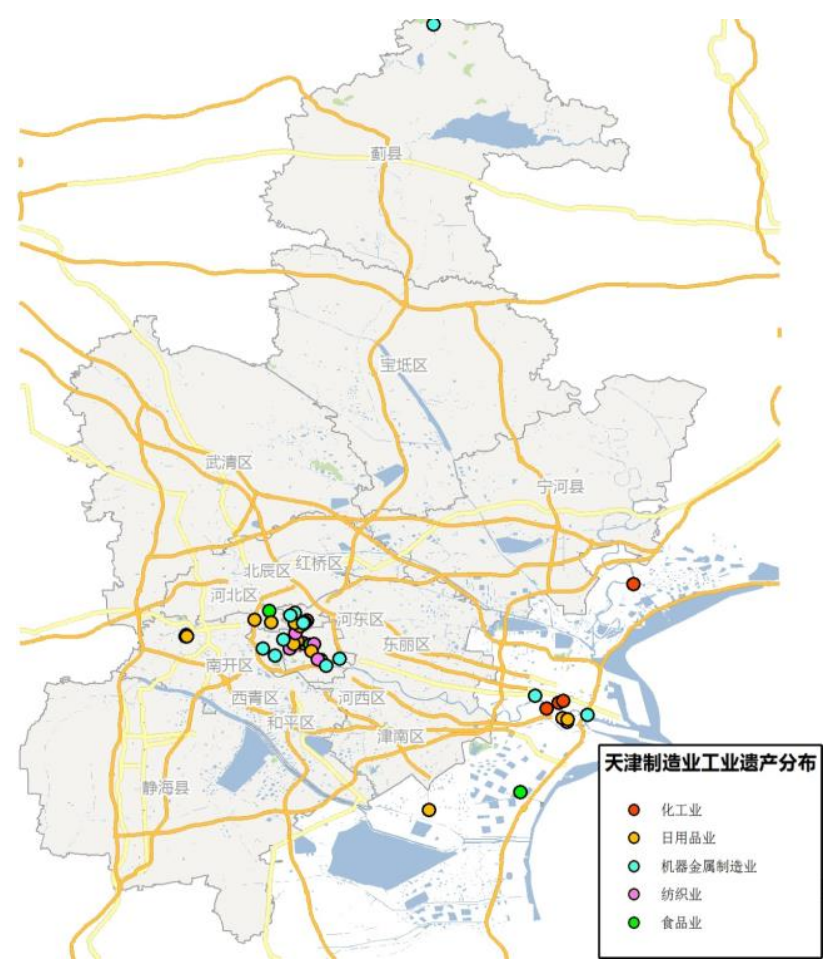

Figure 4. Spatial distribution and industry types of the industrial heritages in Tianjin

\section{DATABASE OF DAGU DOCK}

\subsection{Structure of physical property data organization}

Main content of the proposed database integrates GIS and BIM to organized 3D buildings, urban and landscapes with attributed social and cultural phenomena in order to record the industrial heritage comprehensively and profoundly for heritage management and further application. As mentioned in previous section, physical properties including courtyards, buildings, manufactural facilities, environmental settings and other relevant urban features are depicted through 3D objects. While intangible social/cultural phenomena are recorded as semantics of the 3D spatial elements. According to the LOD format of CityGML models, objects standing for heritage properties are organized hierarchically to reflect different levels of scale, and then modelled in different LOD.

1. LOD0. Besides traditional LOD0 features like the natural landscape, environmental setting, etc., heritage property unit defined by an enclosed spatial boundary, including factory, dock, dyke, or group of buildings, facilities, contaminated areas, as well as the factory, construction and dock in the historical period are depicted through BREP in this level. Format of these units are polygons draped on the DEM and extruded into $3 \mathrm{D}$.

2. LOD1. Individual building are the only component in this level and expressed as simple blocks (see Figure 5).

LOD2. A few significant buildings, all trees and environment features, and other landscape architecture elements are depicted in LOD2 since they need to be recorded and illustrated in detail. Special styles and shapes of buildings, and textures of landscapes features are recorded in LOD2 models. Accuracy of details of LOD2 models may even finer than the typically suggested 2/2 meters in the CityGML standard (OGC, 2007).

4. LOD3 and LOD4. More detailed elements, such as structural elements, changing process (see Figure 6), damaged condition of important buildings (see Figure 7), special structure or facility of the industrial heritage, like crane beam, are managed in BIM and transferred into LOD3 and LOD4 levels.

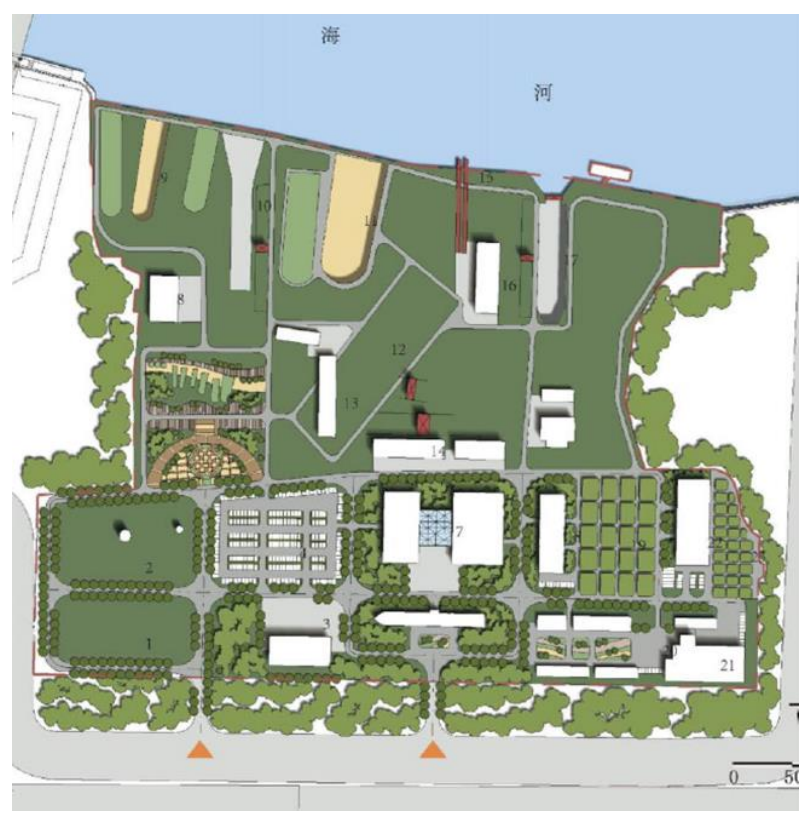

Figure 5. LOD1 heritage records of Dagu Dock of Beiyang Navy (International Research Center for Chinese Cultural Heritage Conservation of Tianjin University, 2014)

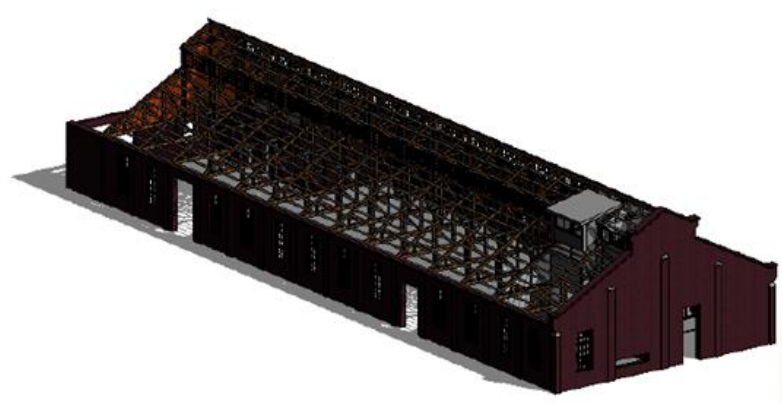

Figure 6. Post-earthquake machinery engineering workshop, Dagu Dock of Beiyang Navy (International Research Center for Chinese Cultural Heritage Conservation of Tianjin University, 2014) 


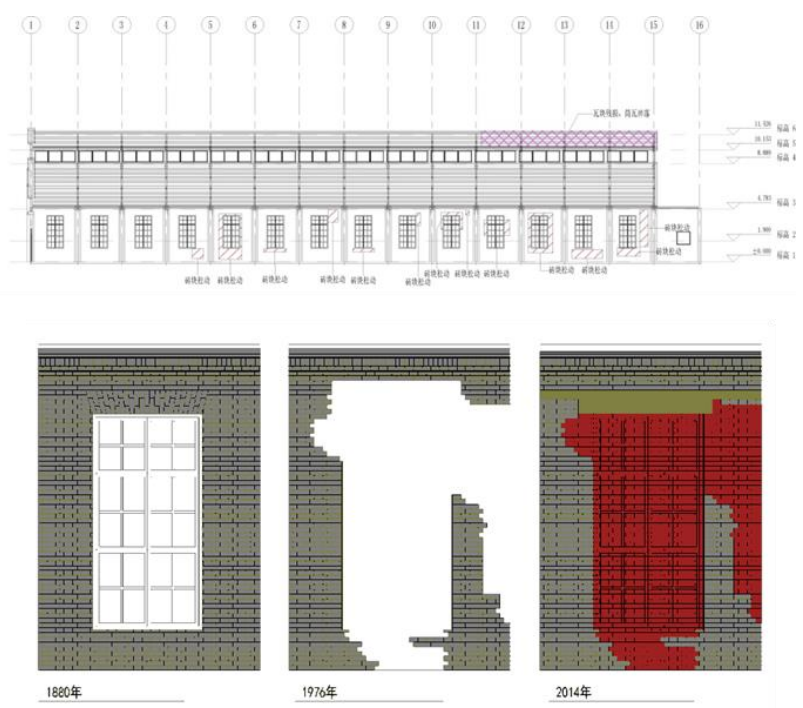

Figure 7. The wall damage documentation and partial inner wall changes of machinery engineering workshop, Dagu Dock of Beiyang Navy (International Research Center for Chinese Cultural Heritage Conservation of Tianjin University, 2014)

\subsection{Attribute Data of Intangible Phenomena}

History and social/cultural phenomena, as mentioned in the above sections, are recorded as semantics and indexed to the heritage properties. The major semantics the properties' physical existences are functionality categories, text descriptions, temporal changes, industrial behaviours, continuity and sustainability, multimedia records and so on. Table 2 shows what kind of attribute information are required to record important properties of the factory, buildings /structures and machineries:

\begin{tabular}{ll}
\hline Heritage property & \multicolumn{1}{c}{ Categories of attribute data } \\
\hline Factory & $\begin{array}{l}\text { Name, industry category, construction time, } \\
\text { protection level, major products, present situation } \\
\text { description, main technology, important historical } \\
\text { moments/figures and events, document information, } \\
\text { etc. }\end{array}$ \\
\hline Building/structur & $\begin{array}{l}\text { Name, construction time, critical historical } \\
\text { moment/figures and events, document information, } \\
\text { present situation description, protection level, etc. }\end{array}$ \\
\hline Machine & $\begin{array}{l}\text { Name, manufacture date, model, product } \\
\text { specifications, manufacturer, trade mark, function, } \\
\text { present situation description, document information, } \\
\text { etc. }\end{array}$ \\
\hline
\end{tabular}

Table 2. Attribute data documented for different categories of heritage property

\subsection{Database Application}

The proposed database directly serves as the analytical base of in-depth and multidisciplinary studies. Investigation on building and structure levels depends on the BIM data, while the historical interpretation and spatial phenomena are explored base on the spatial and semantic data. According to historical records and literature data (Chi, 1930; Culture \& History Committee, Tanggu CPPCC, 2005; Zhou, 1907), the research team analyses the history of Dagu dock from 1695, the year when Emperor Kangxi of the Qing Dynasty ordered to rebuild The Sea God Temple, to 1942 (Figure 8). Spatial construction of the Dagu Dock is basically around the Sea God Temple which is marked as the yellow rectangle in figure 8. Its was originated from the Chinese architectural tradition that the significant building usually locates in the center and in consequence the Temple plays an important role in the spatial distribution. People worshiped the Dragon King (the god manage the sea) before shipbuilding, ship repair, and the launch of a new ship and going out to sea (Jiang, 2005). This confirms the combination of early modern industrial civilization and Chinese traditional sacrifice culture.

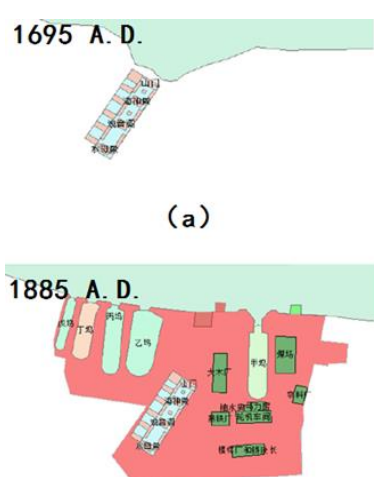

(c)

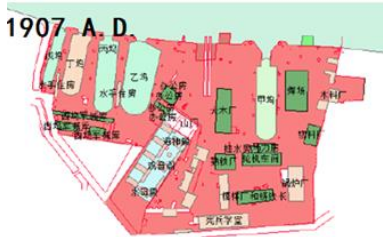

(e)

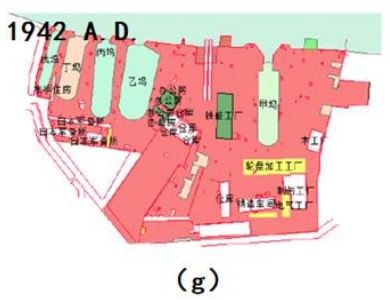

(g)

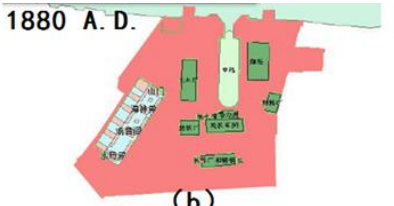

(b)

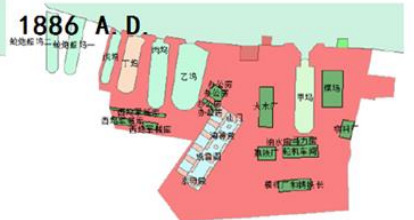

(d)

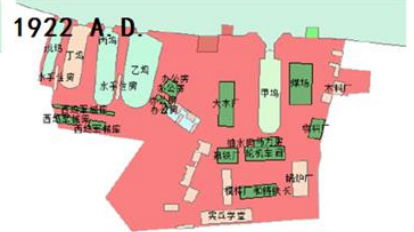

( $f$ )
Figure 8. Historial development map of Dagu dock (1695-1942 A.D.)

\section{CONCLUSION AND DISCUSSION}

This paper illustrates the idea of continuous scales through a specific case study. Since our regional-scale study of industrial heritage of China was just started from the initiation of this comprehensive GIS-based approach, it is still in its primary stage comparing the more mature database of site and buildings. In addition, spatial and temporal social and cultural distribution demonstrated by industrial heritage and their mechanism cannot be interpreted clearly due to lack of theory and methodology. Therefore this part is not discussed in the limited content of this paper. On the other hand, although there are other cases which may explain the continuous scales in larger scales properly, but not suitable from the BIM aspect. Paradigm shift in these scales usually happens within a building. The case study proposed in this paper still can demonstrate the most typical component of this framework. 


\section{ACKNOWLEDGEMENTS}

This paper and presented researches are supported by the following research funds: Key Project of National Social Science Foundation of China (project No. 12\&ZD230); National Major Science and Technology Development Project of China (project No. 2014BAK09B02); Programme of Introducing Talents of Discipline to Universities of Ministry of Education of China (project No. B13011); and Natural Science Foundation of China (Project No. 51178293). The authors appreciate Dr. Zhu Lei's contribution at the earlier stage of this academic idea as well as the prototype of GIS-BIM integration system.

\section{REFERENCES}

Al Amouri, A. and Kolbe, T. 2009. Quality assessment of historical Baalbek's 3D city model. In: Digital heritage: Proceedings of the third international Conference, Lund, EuroMed, pp. 121-125.

Box, P. (eds.), 1999. Geographic Information Systems and Cultural Resource Management: A Manual for Heritage Site Managers. Bangkok: UNESCO Principal Regional Office for Asia and the Pacific.

Du, X., 2013. BIM-based industrial architectural heritage mapping. Tianjin: Master's thesis of Tianjin University.

\section{Chi, Z. Y.(池仲佑),1930. 海军实记. 中国国家图书馆古籍善本} 影印本, National Library of China, Beijing.

Culture \& History Committee, Tanggu CPPCC, 2005. 北洋水 师大沽船坞. China Culture and History Press, Beijing.

Fletcher, R., Johnson, I., Bruce, E. and Khun-Neay, K., 2007. Living with heritage: site monitoring and heritage values in Greater Angkor and the Angkor World Heritage Site. World Archaeology, 39(3), pp.385-405.

He, J., 2008. GIS-based Cultural Route Heritage Authenticity Analysis and Conservation Support in Cost-surface and Visibility Study Approaches. Hong Kong: PhD thesis of The Chinese University of Hong Kong.

Hu, M. X. and Dong, W., 2002. GIS-based information systems of Xijindu historical town of Zhenjiang protection and management. PLANNERS.(3) pp.71-73.

Gröger, G. and Plümer, L., 2012. CityGML - interoperable semantic 3D city models. ISPRS Journal of Photogrammetry and Remote Sensing, 71, pp.12-33.

Isikdag, U. and Zlatanova, S., 2009. Towards defining a framework for automatic generation of buildings in CityGML using building information models. In Lee, J., Zlatanova, S., Cartwright, W., Gartner, G., Meng, L. and Peterson, M. P.(eds.), 3D Geo-Information Sciences. Springer, Berlin and Heidelberg, pp.79-96.

Liu, H. Y., 2013. formationalizing the Architectures in Hexi Corridor based on CGB Technique. Tianjin: Master's thesis of Tianjin University

Laat, R. and Berlo, L., 2011. Integration of BIM and GIS: the development of the CityGML GeoBIM extension. In Kolbe, T.
S., König.,G,, Nagel, C., Cartwright, W., Gartner, G., Meng, L. and Peterson, M. P.(eds), Advances in 3D Geo-Information Sciences. Springer, Berlin and Heidelberg, pp.211-225.

Limp, W. F., Payne, A., Winters, S., Barnes, A. and Cothren, J. 2010. Approaching 3D digital heritage data from a multitechnology, lifecycle perspective. In: Proceedings of The 38th Conference on Computer Applications and Quantitative Methods in Archaeology [C/OL]. http://www.cast.uark.edu/assets/files/PDF/CAA_2010_proceedi ngs_Limp_et_al.pdf (31.Dec.2012)

Manferdini, A. M., and Remondino, F., 2010. Reality-based 3D modeling, segmentation and web-based visualization. In: Digital heritage : Proceedings of the third international Conference, Lemessos, EuroMed, pp. 110 - 124.

Open Geospatial Consortium, Inc. (OGC). 2007. Candidate OpenGIS ${ }^{\circledR}$ CityGML Implementation Specification. [R/OL] Open Geospatial Consortium Inc.. OGC 07062,http://portal.opengeospatial.org/files/?artifact_id=22120\&p asscode $=$ hfbq2pa6eprrnh9jbyzp (1 Jan. 2013)

Oreni, D., Cuca, B. and Brumana, R., 2012. Three-dimensional virtual models for better comprehension of architectural heritage construction techniques and its maintenance over time. In Ioannides, M., Fritsch, D., Leissner, J., Davies, R., Remondino, F. and Caffo, R. (eds), Progress in Cultural Heritage Preservation. Berlin Heidelberg, Springer, pp. 533542.

Pauwels, P., Verstraeten, R., De Meyer, R. and Van Campenhout, J.,2008. Architectural information modelling for virtual heritage application. In: Digital Heritage -- Proceedings of the 14th International Conference on Virtual Systems and Multimedia, Limassol, pp.18-23.

Rojas-Sola, J.I., Castro-Garcia, M. and del Pilar CarranzaCanadas, M., 2011. Content management system incorporated in a virtual museum hosting. Journal of Cultural Heritage, 12(1), pp. 74-81.

Riveiro, B., Arias, P., Armesto, J. and Ordóñez, C., 2011. A methodology for the inventory of historical infrastructures: documentation, current state, and influencing factors. International Journal of Architectural Heritage, 5(6), pp.629646.

Remondino F. 2011. Heritage recording and 3D modeling with photogrammetry and 3D scanning. Remote Sensing, 3(6), pp.1104-1138

San José-Alonso, J. I., Finat, J., Pérez-Moneo, J. D., FernándezMartín, J. J., and Martínez-Rubio J., 2009. Information and knowledge systems for integrated models in cultural heritage [C/OL]. In: Proceedings of 3D-ARCH 2009: $3 D$ Virtual Reconstruction and Visualization of Complex Architectures. http://www.isprs.org/proceedings/XXXVIII/5-

W1/pdf/sanjosealonso_etal.pdf (7 Dec. 2012)

Styliadis, A. D., Akbaylar, I. I., Papadopoulou, D. A., Hasanagas, N. D., Roussa, S. A. and Sexidis, L. A., 2009. Metadata-based heritage sites modeling with e-learning functionality. Journal of Cultural Heritage, 10(2), pp.296-312.

Tsirliganis N, Pavlidis G, Koutsoudis A, Papadopoulou D, Tsompanopoulos A, Stavroglou K, Loukou Z and Chamzas C. 
2004. Archiving cultural objects in the 21 st Century. Journal of Cultural Heritage, 5(4): 379-384

International Research Center for Chinese Cultural Heritage Conservation, the general plan for the protection of Dagu Dock of Beiyang Navy（2015-2030）. Tianjin :Tianjin University

TICCIH, 2003. The Nizhny Tagil Charter for the Industrial Heritage, http://ticcih.org/about/charter/ (15 July. 2015)

Wu, C., Wu, S., Liu, F., He, X. and Gu, J., 2011. Application of BIM on Angkor Monuments: a case study on documentation and research of the South Outer Gopura in Ta Keo Temple, Angkor Monuments. Proceedings of East Asian Architectural Culture International Conference (EAAC 2011). Singapore: National University of Singapore.

Wheatley, D. and Gillings, M., 2002. Spatial Technology and Archaeology: The Archaeological Applications of GIS. Taylor $\&$ Francis, London and New York.

Wager, J., 1995. Environmental planning for a world heritage site: Case study of Angkor. Journal of Environmental Planning and Management, 38(3), pp.419-434.

Wu, L. L., 2012. Study on the Lifecycle Management System of Architectural Heritage Information based on ArcGIS. Tianjin: Master's thesis of Tianjin University.

Wu, C., Wu, S., Liu, F., He, X. and Gu, J., 2011. Application of BIM on Angkor Monuments: a case study on documentation and research of the South Outer Gopura in Ta Keo Temple, Angkor Monuments. In: Proceedings of East Asian Architectural Culture International Conference (EAAC 2011). Singapore: National University of Singapore

Zhang, R., 2008. The research in protection of the historical environment in conservation planning of the of cultural relics : a case study of Jiexiu Temple. The Journal of Architecture, (03)pp. 88-93

Zhang, R., 2010. survey and research of the East Hall of Fougang Temple. Journal of ancient garden technology, (03)pp. 29-39.

Zhou, E. R.(周尔润), 1907. 直隶工艺志初编, Beiyang Official Newspaper Bureau, 1907

Zhou, W. S., Huang, J. X., 2011. Application of spatial information technology in the Beijing-Hangzhou Grand Canal cultural heritage protection. Science Publishing, Beijing. 